\title{
POPULATION CONTROL IN JAPAN: AN ECONOMIC THEORY AND ITS APPLICATION"
}

\author{
Martin Bronfenbrenner† and John A. Buttrick $\ddagger$
}

The so-called "classical" economists (Smith, Malthus, Ricardo, and their successors) embedded an economic theory of population in their general economics of growth and development. ${ }^{1}$ With the "utility revolution" of the I870's, however, economists turned away from population problems, which passed largely by default into the hands of the rising science of sociology.

A revival of interest in the economics of population has accompanied renewed attention to the development problems of the less-developed areas within the last generation and particularly since the end of World War II. Two representative contemporary American economists who have specialized on population problems are Joseph J. Spengler ${ }^{2}$ and Harvey Liebenstein. ${ }^{3}$

Part one of the present paper is devoted to an elementary version (largely diagrammatic) of a contemporary economic theory of population growth, with population related as both cause and effect to the level of per capita income. Parts two and three attempt to apply this analysis to Japan during its period of seclusion

* This paper is a product of the University of Minnesota Workshop in Economic Development, conducted jointly by the writers. Professor Bronfenbrenner takes primary responsibility for institutional material relating to Japan, and Professor Buttrick for theoretical material relating to population in general. Both writers are economists with lily-white amateur standing in demography.

† A.B. I934, Washington University; Ph.D. I939, University of Chicago; Certificate in Japancse Language 1944, United States Navy and University of Colorado. Professor of Economics, University of Minnesota. Author, Long-Range Projections of JaPanese Economy, 1962-1975 (1958). Contributor to economics and population periodicals.

¥ B.S. I94x, Haverford College; M.A. 1947, Ph.D. I950, Yale University. Professor of Economics, University of Minnesota. Author, [with H. F. Williamson] Economic Development: Principles AND PAtTerns (1954). Contributor to economics and population periodicals.

${ }^{1}$ For a "classical model" of economic growth, see Benjaxin H. Higgins, Economic Development: Principles, Problems, and Policies ch. 3 (1959). The present writers would modify the algebra of Higgins's general equilibrium presentation at pp. 87-99.

"Spengler represents the "older generation" of American population economists. Two available samples from his extensive bibliography are the chapter on Population Theory, in 2 B. F. HALEY (ED.), Survey of Contemporary Economics 83 (1952), and the chapter on Demographic Patterns, in Hanold F. Williamson \& John A. Buttrick (Eds.), Economic Development: Principles and Patterns 63 (1954).

${ }^{3}$ Liebenstein represents the "younger generation" of American population economists. His major contributions are embodied in' Harvey Liebenstein, A Theory of Economic Democraphic Develop. MENT esp. chs. 4, 5, and 6 (1954), and in Economic BACKWARDNESS AND Economic Growth esp. chs. 3 I0, and 14 (1957). The writers' formal argument has also been anticipated in part by Nelson, The Low-Level Equilibrium Trap in Underdeveloped Countries, 46 AM. Econ. Rev. 894 (1956); Hagen, Population and Economic Growth, 49 id. at 310, 316, esp. § II (1959). 
(the Tokugawa shogunate) and since its opening in $1853^{4}$ The primary stress of part two is on the period prior to I945, while part three concentrates on later developments.

An Economic Theory of Population Growth

A national economy may be regarded as a single gigantic firm producing a composite output called "national income," with three composite inputs called "labor," "land," and "capital." At the outset, we suppose that the amounts of land (including all natural resources) and capital (including all produced resources) are fixed; we also suppose that the technology by which the flow of inputs is transformed into a flow of output is unchanged. As a result, we may write a production function $Y=f(L)$, which indicates the relation between $L$ (labor) and $Y$ (national income). As drawn on figure one, this function gives the appearance of increasing returns for small values of $L$, since the ratio of output to input $(Y / L)$ increases until $L=L_{0 .}{ }^{5}$

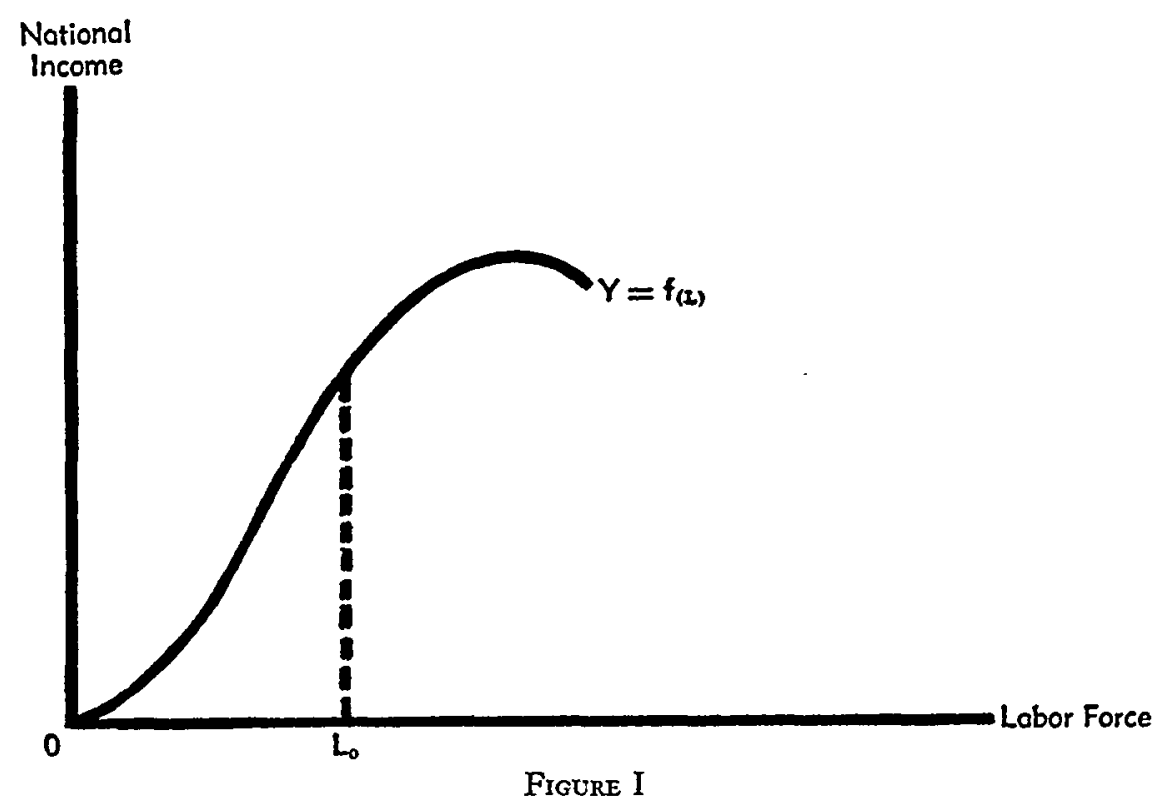

'This is not the first time that Japanese experience has been used to test population theories. For an carly attempt (incompletely successful, in our view) to apply the theory of "optimum population" to Japan, see E. F. Penrose, Population Theories and Their Application, With Special Reference to JAPAN (I934).

¿This discussion runs in terms of the average product of labor. Many economists prefer to distinguish between increasing, constant, and diminishing returns in terms of the marginal product of labor, as measured by the slope of the production function or by the expression $(d Y / d L)$. See K. E. Boulding, Economic Analysis chs. 28, 34 (3d ed. i955); George J. Stigler, Theory of Price ch. 7 (rev. ed. I952). 
For larger values of $L$, the function gives the appearance of diminishing returns to labor, since the ratio $(Y / L)$ decreases as $L$ rises."

From the production function of figure one, it is easy to derive figure two. This diagram relates population $(n)$ and income per capita $(Y / n)$, under the simplifying assumption that an approximately constant fraction of the population is included in the labor force at each level of $(Y / n)$. The function drawn in figure two may be written: $(Y / n)=\varphi(n)$. It has its maximum value at $n_{0}$, which corresponds to $L_{0}$ in figure one. Any improvement in technology or increase in the supply of land and capital will cause the function $O$ to "shift upward," although its new position need not parallel its old one.

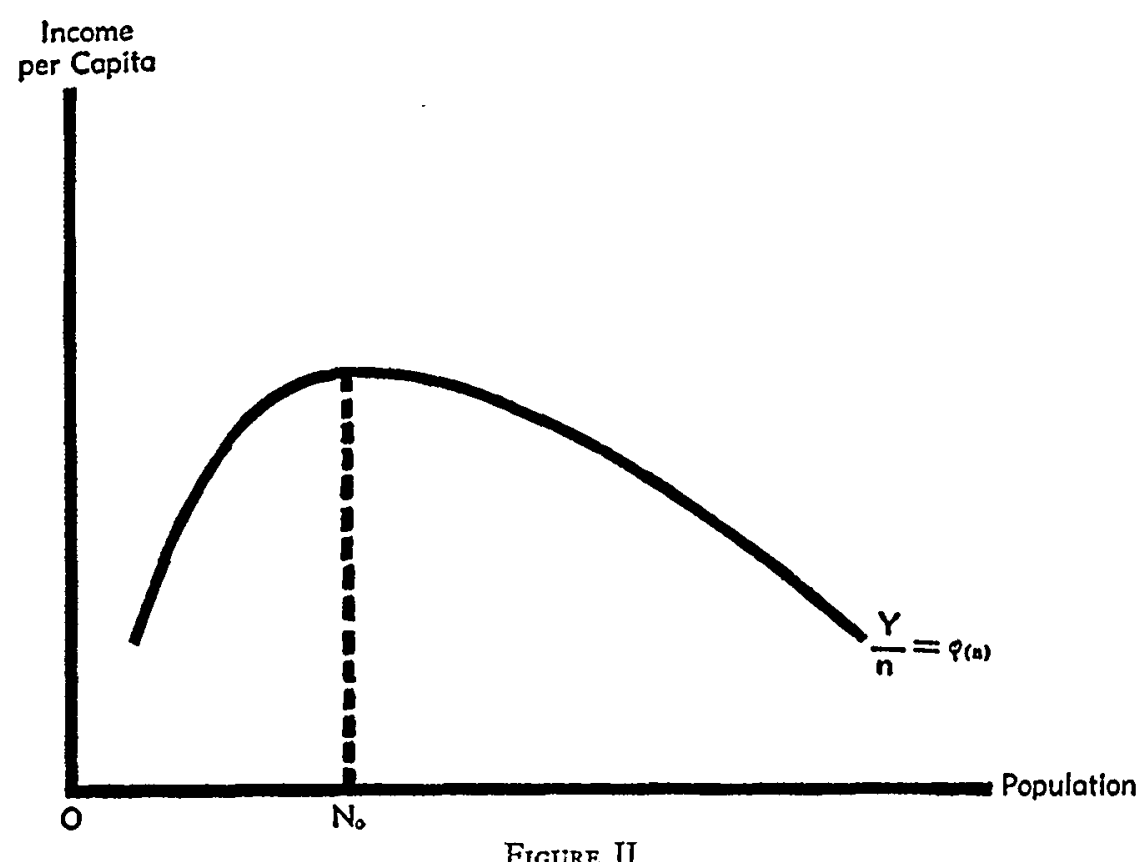

In addition to these production functions, evidence suggests the existence of demographic relationships between population and income. Whereas it is natural to view causation as running from population to income on the production side, it is equally natural to view causation as running the other way on the demographic side.

The death rate (the number of deaths per rooo persons annually, either adjusted or unadjusted for differences in age distribution) is probably related inversely to per capita income. That is to say, the higher the per capita income, the lower the death rate and the longer the life expectancy at any age. Some doubt arises as to this proposition at the highest income levels; Americans in particular have been accused

\footnotetext{
"Marxists deny the relevance of the "law of diminishing returns" to labor. This is because they deny that labor can, in fact, increase in quantity without accompanying increases in the quantity of land and capital, not to mention improvements in the quality of labor and in the technology available.
} 


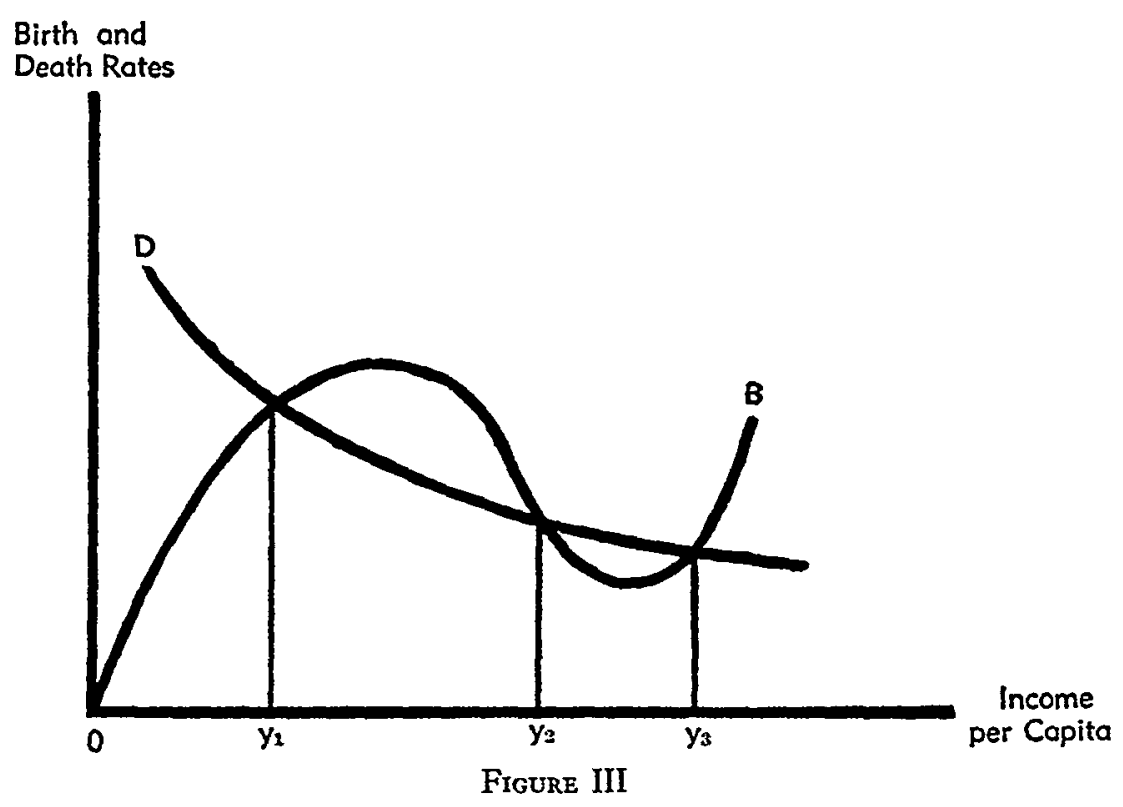

of "digging their graves with their teeth." At lower levels, however, we use it without hesitation.

The relationship of the birth rate to per capita income is more complicated, and the evidence is understandably ambiguous. We shall however assume this relationship to be as pictured in figure three. As income per capita increases from extremely low levels, the birth rate also increases, partly because marriages take place earlier and partly because more parents survive into and beyond their fertile ages. ${ }^{7}$ Later, as incomes continue to rise, the population becomes more urbanized and the birth rate falls. With improved sanitation, a smaller number of births suffices to produce a given number of young adults. The prospect also opens up of improving the quality of children by investment in their education. ${ }^{8}$ The net cost of raising children rises, while the income produced by children falls. Finally, at still higher levels of income, families can afford to pass much of the drudgery of child-raising to others, while retaining the pleasures themselves. Furthermore, families are able to provide "advantages" for larger numbers of children. The birth rate tends, accordingly, to increase once more.

Summarizing bluntly: Children may be viewed as both consumers' and producers' goods. As consumers' goods, we should normally expect more to be "purchased" as income rises; however, this simple statement assumes the "quality" of children to be constant. With urbanization and higher incomes, however, the relative cost of

${ }^{7}$ We should not forget another relation involving causation in the opposite direction. A high birth rate acts with a relatively short lag to increase the child labor supply, which increases income.

${ }^{8}$ At the same time, humanitarian' folkways develop to diminish the amount of child labor mentioned in the preceding note, and to increase the lag between the child's birth and his availability on the labor market. 
improving quality (by additional education, better food and clothing, etc.) rises as the standards for a "minimal" socially acceptable child improve. With a still higher per capita income and a generally affluent society, the productivity of expenditures on education, etc., decreases at the margin, ${ }^{9}$ and increases in number become more attractive than increases in quality. ${ }^{10}$

When children are viewed as producers' goods, the situation is otherwise. In an underdeveloped agricultural society, children are cheap to manufacture and likewise productive. They help with the harvest and participate in cottage industry while still young. They assure their parents secure old age as adults. With industrialization and the shift to small "nuclear" families, children serve less well as social security at the same time that they become more expensive to produce and shelter. Their productivity to their parents falls not only because of laws and taboos against child labor, but because of children's greater independence in adult life. On these grounds, industrialization should result in a steady lowering of the birth rate.

Combining the two halves of this analysis, we should expect the birth rate to rise with per capita income until agriculture loses its dominant position in the economy. Then birth rates should fall with urbanism and industrialization until per capita income rises enough to bring about an affluent society and a reversal of the urban trend. ${ }^{11}$

Figure three puts these arguments in diagrammatic form, showing both the birth rate $B$ and the death rate $D$ as functions of per capita income $(Y / n)$. Writing $y$ for $Y / n$, we find that at incomes below $y_{1}$, deaths will exceed births and the population will vanish with the passage of time. Incomes between $y_{1}$ and $y_{2}$, and likewise incomes larger than $y_{3}$, will generate increasing populations in which the percentage of young people is relatively large. Incomes between $y_{2}$ and $y_{\mathfrak{i}}$, however, will generate excesses of deaths over births, population will decline, and the percentage of old people will be relatively large. Stationary populations are consistent with incomes of $y_{1}, y_{2}$, or $y_{3}$. The lowest of these, $y_{1}$, may be defined as the Malthusian "subsistence level" of per capita income. There is, however, no con-

${ }^{\circ}$ In an affluent society, even a minimal education suffices as reasonable assurance of a satisfactory income level for children' and "vicarious consumption" by parents, as witness the steady fall of the "white-collar differential" in the United States labor market. This is a major cause of the declining marginal productivity of expenditures aimed at improving the quality of children in such a society.

${ }_{10}$ The essentially rational view of children as consumption goods contrasts with that of $W$. W. Rostow, who uses similar terminology. Rostow suggests that the recent rises in birth rates have occurred "as Americans (and others in societies marked by high mass consumption) have appeared to seek in larger families, values beyond those afforded by economic security and by an ample supply of durable consumers goods and services." And again, ". . . what to do when the increase in real income itself loses its charm? Babies; boredom; three-day weekends; the moon; or the creation of new inner, human frontiers in substitution for the imperatives of scarcity?" Rostow, The Stages of Economic Growth, 12 EcoN. Hist. REv. (2d ser.) I, at 3 (I959). Since Rostow's concept of consumption is more restricted than ours, the difference between us may be largely verbal.

${ }^{11}$ Statements about the influence of urbanism on population are dificult to test. We use the term as excluding the suburban "bedrooms," which are often equal in size to small cities and are treated as "urban" in conventional census statistics. White Plains and Evanston are American-Musashino and Nishinomiya, Japanese-examples of communities that require reclassification for statistical verification of our statements. 
nection between this notion and the relatively useless notion of biological subsistence. Economic subsistence income, like Ricardo's "natural rate of wages," is merely the lowest per capita income associated with a stationary population.

The birth and death rate functions presented on figure three will presumably shift with changes in technology or mores. Improvements in medical knowledge will lower the death rate associated with each level of per capita income. Improvements in contraception or increases in urbanization (uncorrelated with income) would probably have the same effect on the birth rate associated with each level of income.
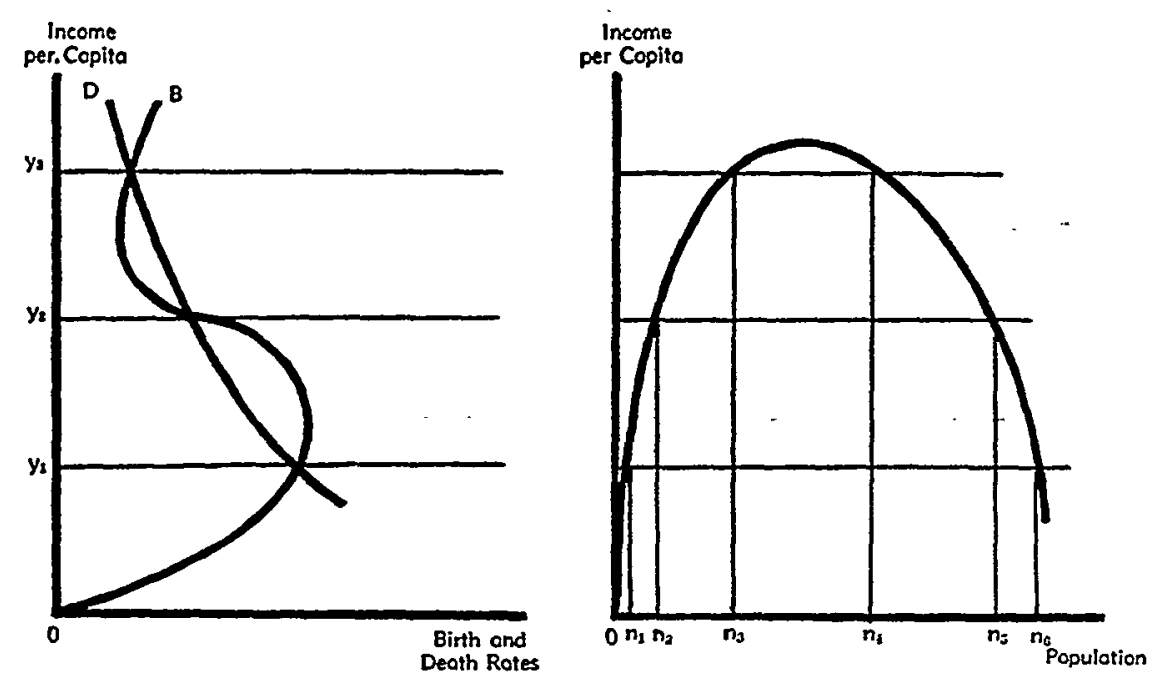

Figure IV

Our next step is to combine these two strains: (a) birth and death rates as functions of per capita income, and (b) per capita income as a function of population. This is attempted in figure four, a diagram that appears more complex than the earlier three, since it requires two panels. The left panel, however, is only figure three with its axes reversed, while the right panel is simply figure two. Figure four shows six population levels $\left(n_{1}, n_{2}, \ldots, n_{6}\right)$ that if achieved, maintain themselves, both in the sense of a balance between births and deaths and in the sense of producing income adequate for their maintenance. To these six equilibrium populations, we should perhaps add a trivial seventh, the origin, with a zero population. Only three of these six levels (or four if we include the origin), however, can be regarded as stable.

With an initial population less than $n_{1}$, income produced will be so small that deaths will exceed births and the population will eventually vanish from the face of the Earth. A population between $n_{1}$ and $n_{2}$ will produce income such that births will exceed deaths. The population will raise to $n_{2}$. A population between $n_{2}$ and $n_{3}$, on the other hand, will produce income such that deaths will exceed births and 
lower the population to $n_{2}$. Therefore, we argue that level $n_{2}$ is stable, while levels $n_{1}$ and $n_{3}$ are unstable. Small departures from level $n_{2}$ will tend to correct themselves, while small departures from $n_{1}$ or $n_{3}$ will tend to augment themselves. Similarly, a population between $n_{3}$ and $n_{5}$ will tend to settle at the stable level $n_{4}$, and a population in excess of $n_{5}$ will tend to settle at the stable level $n_{6}$.

With each stable population level $\left(n_{2}, n_{4}, n_{\mathfrak{\varepsilon}}\right)$ is associated a correspondingly stable level of per capita income $\left(y_{2}, y_{3}, y_{1}\right.$, respectively), so that we may speak of stable pairs of points or stable solutions of our model. In order of population size, these pairs or solutions are $\left(n_{2}, y_{2}\right),\left(n_{4}, y_{3}\right)$ and $\left(n_{6}, y_{1}\right)$. They may be looked upon as representing "underpopulation with underdevelopment," "adequate population with adequate development," and "overpopulation with underdevelopment." None of the three necessarily coincides with an "optimum" population, as will be shown later.

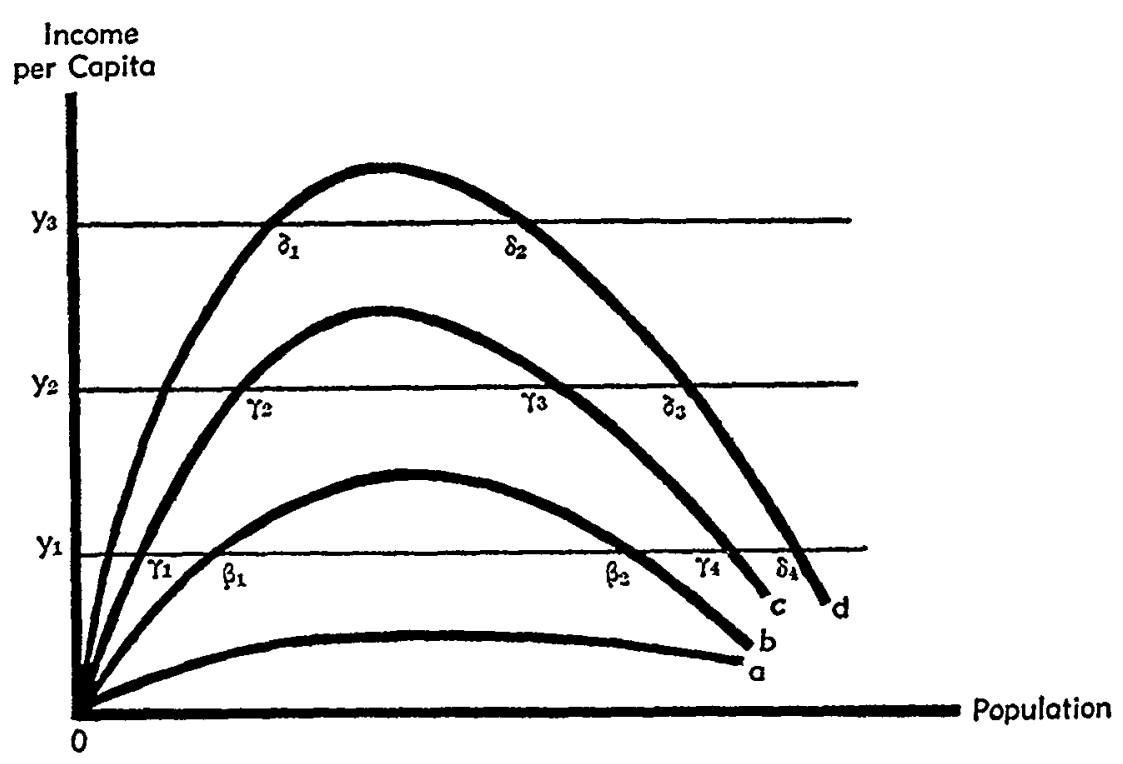

Figure V

The next complication has already been mentioned briefly, and will have occurred to many readers independently. The production functions $Y=f(L)$ and $y=\varphi(n)$ are normally rising over time, as technology improves and the capital stock increases. This feature enters our diagrams with figure five, which reproduces the right panel of figure four with four possible per capita production functions shown separately. These are labeled $a, b, c$, and $d$; they are only representative samples from the infinite family of possible functions. Each function is associated with a different capital stock and a different technology, $a$ being most primitive and $d$ most advanced. It is possible for production functions to cross, although they do not do so on this diagram. 
So long as an $a$ curve is in effect, the economy will eventually die out, because the maximum per capita income possible with this production function is less than the minimum income level $y_{1}$ at which the population will sustain itself. With a $b$ curve in effect, either a zero or a "subsistence" population may result; the "subsistence" population is the level of $n$ associated with income level $y_{1}$ at point $\beta_{2}$, and will be reached if population is initially above $\beta_{1}{ }^{12} \mathrm{~A} c$ curve will permit a stable per capita income level of either $y_{1}$ or $y_{2}$. A population that was initially sparse will settle at point $\gamma_{2}$. A population that was initially dense will settle at point $\gamma_{4}$. The watershed or divide is at point $\gamma_{3}{ }^{13}$ A Malthusian conclusion seems to follow in this case; the stable income level $y_{2}$ corresponding to the smaller population is larger than the stable income level $y_{1}$ corresponding to the larger population. Only with a production function like $d$ can the high per capita income $y_{3}$ be maintained (point $\delta_{2}$ ). Even here, less favorable outcomes are possible if the initial population level is either too low (below point $\delta_{1}$ ) or too high (above point $\delta_{3}$ ). ${ }^{14}$

An "optimum" population, defined as that associated with a maximum per capita income, has little analytical significance in this model. Only by coincidence would an equilibrium population equal an optimum population, and it would be stable in only one direction (upward). ${ }^{15}$ To argue convincingly in favor of attempts to influence birth and death rates with an eye to achieving and maintaining this equality would require value judgments of unusual strength and narrowness.

Before passing on to Japan, we present three other illustrations to which this theory may be relevant:

I. The formation of the great deserts of Central Asia was perhaps reflected in a fall of the per capita production function for nomadic agriculture from a $b$ to an $a$ type. This left the population no choice beyond extermination and migration. The great barbarian invasions of the first milennium of the Christian Era have been presented as possible results.

2. Colonial America may be thought of as having a $b$-type production function and as being located somewhere to the right of $\beta_{1}$ in figure five, with per capita income somewhat in excess of $y_{1}$. Births exceeded deaths, and population grew rapidly (even disregarding immigration). Before the growth of population could pull per capita income down to the $y_{1}$ or subsistence level, however, technological improvements, capital formation, and the opening of new lands combined to replace a $b$ by a $c$-type production function. Continued immigration raised population somewhat above the point indicated by $\gamma_{2}$ in figure five and per capita income somewhat above $y_{2}$. Shifts in the birth and death rate functions, particularly the latter, combined with continued immigration to prevent any actual excess of births over deaths or

${ }^{12}$ Point $\beta_{1}$ corresponds to the unstable equilibrium point $\left(n_{1}, y_{1}\right)$ of fig. IV.

${ }^{23}$ Point $\gamma_{3}$ corresponds to the unstable equilibrium point $\left(n_{5}, y_{2}\right)$ of fig. IV.

${ }^{14}$ Points $\delta_{1}$ and $\delta_{3}$ correspond, respectively, to the unstable equilibrium points $\left(n_{3}, y_{3}\right)$ and $\left(n_{5}, y_{2}\right)$ of fig. IV.

${ }_{16}$ Points $\left(n_{3}, y_{3}\right)$ and $\left(n_{4}, y_{3}\right)$ of fig. IV would coincide at this optimum point. The first point is unstable, the second stable. 
reduction in population. The rate of growth of population, however, declined, as did the rate of growth of income. Fear was expressed of "economic maturity" or "economic stagnation" as a result; ${ }^{10}$ this would be interpreted in our diagrams as an income contraction to $y_{2}$. Before it occurred, however, further improvements in technology and further accumulation of capital replaced the c-type production function by a $d$-type function, creating the possibility of stable equilibrium at the higher per capita income level y3. Present-day America may, in fact, be thought of in our terms as located somewhat to the left of $\delta_{2}$ on figure five. Income is higher than $y_{3}$, and population is increasing. But the effects of the population increase on the income level will perhaps be offset by a continued rise in the production function.

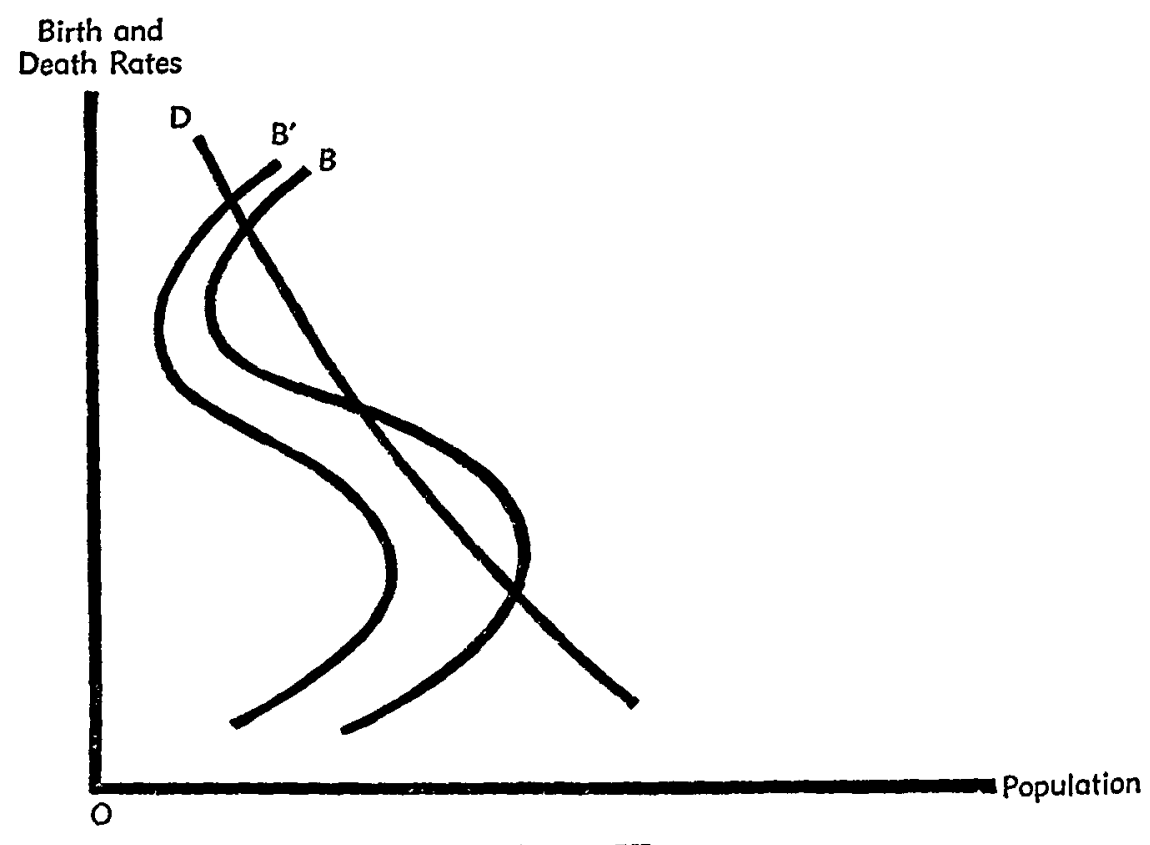

Figure VI

3. We can depict India and Pakistan as having had for centuries a production function of the $b$-type and per capita income fluctuating about the subsistence level $y_{1}$. In terms of figure five, the Indian subcontinent was located close to point $\beta_{2}$. As the years passed, the production function has risen from a $b$ to a $c$-type, but so slowly that per capita income could not exceed $y_{1}$. Population growth spread the gains from productivity changes over more people, so that a subsistence level of income persisted (points $\beta_{2}, \gamma_{4}$ ). Replacing a $c$-type production function by a $d$-type may also fail to raise per capita income rapidly enough to enable these countries to escape the danger of equilibrium at $\boldsymbol{\delta}_{4}$, the so-called "low-level equilibrium trap."

${ }^{16}$ The standard expression of this apprehension is Alvin H. Hansen's 1938 presidential address to the American Economic Association, Economic Progress and Declining Population Growth, 29 AM. EcoN. Rev. I (1939), which is reprinted in GotTfried Haberler (Ed.), Readings in Business Cycla Theory 366 (I944). 
Under these circumstances, a shift in the birth-rate function $B$ provides a possible avenue of escape. A change in mores such as will diminish the birth rate associated with low incomes (shifting the birth-rate function from $B$ to $B^{\prime}$ in figure six) offers the possibility of reaching and maintaining per capita income levels of $y_{2}$ or $y_{3}$.

\section{II}

\section{Japanese Population: $1720-1945$}

Japanese population history following establishment of permanent contact with the West in 1853 is more difficult to interpret in theoretical terms. From an empirical point of view, the period since 1853 seems divisible into two subperiods, divided by the disaster of World War II.

For perhaps 125 years prior to Commodore Matthew C. Perry's mission of 1853 , the Japanese population had remained constant at 26,000,000 or 27,000,000. An estimate for r72I gives a figure of 26,000,000, while an estimate for 1852 gives one of only $27,200,000 .^{17}$ This generally stable level rose in good crop years and fell in bad ones. It also concealed wide disparities between individual fiefs or kuni, some of which rose or fell by as much as twenty per cent in fifty-year periods. ${ }^{18}$ Nevertheless, the period I720-I850 in Japan is one of the longer and closer approaches to stationary population equilibrium at a subsistence level found in recorded demographic history. In terms of the model presented in part one, changes in agricultural technology dating from the century prior to $1720^{19}$ were after that date raising Japan's production function only gradually, and never enabled per capita income to exceed for long what we have called a subsistence level.

The mechanism of population control under the Tokugawas is not without interest. On the side of the birth rate, contraception and prostitution each played a role. Abortion seems to have been prevalent in the large cities and infanticide in the rural areas, although neither was so frequent as some sensational accounts suppose. Infanticide, called mabiki or "thinning out," was performed by midwives at the behest of the father or the head of the father's family. Its motive among the peasantry was clearly economic. It was also practiced in the warrior or samurai class, where its motive seems to have been the avoidance of economic life. Primogeniture assured samurai status (however poverty-stricken) for the oldest sons of samurai families, but younger sons were in danger of degradation (however

\footnotetext{
${ }^{27}$ Irene B. Taeuber, The Population of Japan 20 et seq. (1958). More detailed estimates of Tokugawa-era population ( 18 in number) are collected in Takuma Terao, AN Outlook of Studies on Population Problems in Japan, IV: Outline of Birth Control Movement 3 (I959).

${ }^{18}$ TAEUBER, op. cit. supra note 17 , at 24 , map 3.

10 This prior century was a period of peace and prosperity under the early Tokugawa shoguns, and culminated in a minor population explosion. It was also marked by the improvements in agriculture and handicrafts described as "the agrarian origins of modern Japan." Cf. T. C. SMith, The Agrarian Origins of MOdern JAPAN esp. chs. 6-8 (r959).
} 
prosperous) to economic activity as members of lower classes. At any rate, the eldest son and the first two or three children of any family faced little risk of mabiki.

Western contact set off a series of decreases in death rates and increases in productivity. Birth rates fell less than proportionately to death rates, perhaps because incomes were also rising. Population rose in a century from 27,000,000 to 90,000,000, as is shown in table one. Japan became, after Holland and Belgium, the world's most densely populated country. ${ }^{20}$

\section{TABLE I}

Population and Annual Growth Rates, Selected Years, Japan, i875-1959

\begin{tabular}{|c|c|c|}
\hline Year & $\begin{array}{l}\text { Population } \\
\text { (millions) }\end{array}$ & $\begin{array}{c}\text { Annual Growth Rate } \\
\text { (per thousand) }\end{array}$ \\
\hline 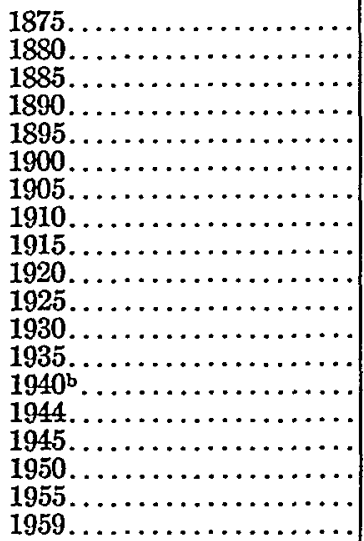 & $\begin{array}{l}35.6 \\
37.0 \\
38.5 \\
40.3 \\
42.0 \\
44.4 \\
47.0 \\
49.9 \\
53.5 \\
55.4 \\
59.2 \\
63.9 \\
68.7 \\
72.4 \\
73.8 \\
72.2 \\
83.2 \\
89.3 \\
93.0\end{array}$ & $\begin{array}{r}8.9 \\
8.6 \\
5.9 \\
8.7 \\
10.5 \\
11.7 \\
9.0 \\
13.6 \\
14.1 \\
13.2 \\
17.5 \\
15.6 \\
13.5 \\
3.9 \\
-22.9 \\
49.9 \\
15.6 \\
11.5 \\
\ldots \ldots\end{array}$ \\
\hline
\end{tabular}

NorEs: a Data prior to 1920 (from local records) are not comparable with later data (from national census estimatcs); Okinawa cxcluded after 1920 .

b Data for 1940 adjusted for troop morements.

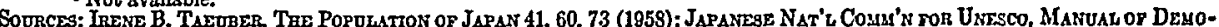

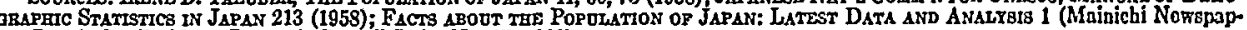
ers, Population Problems Research Council Series No. 17, 1960).

Except for the interruption of World War II, Japanese economic productivity, which we interpret as an upward shift of production functions, permitted the Japanese real national income to rise more rapidly than the Japanese population. Indeed, income per capita rose in index-number terms almost as rapidly as total income until the onset of this war. Figures are shown in table two, although the reader should note the imperfect comparability between prewar and postwar data.

Accompanying this income rise as both cause and effect has been a shift of the Japanese labor force from primary industry (agriculture, forestry, fisheries) to secondary industry (manufacturing, mining, and construction) and to tertiary industry (trade, services, finance, Government). Despite the mushroom growth of

${ }^{20}$ Other exceptions, not classified strictly as "countries," include the Ryukyus and Taiwan in Asia, England and Wales in Europe, and Puerto Rico in North America. See Koseinō Jinkōmondai SHingikn,, Jinkō hakusho [Population Problems Ineuiry Council, Welfare Ministrx, Population Whita PAPER] 158-61, table 29 (1959) [hereinafter cited as Jinkō Hakusho.] 
TABLE II

Indices of Real Income, Selected Periods, Japan, r878-1956

\begin{tabular}{|c|c|c|c|}
\hline \multirow{2}{*}{ Period } & \multicolumn{2}{|c|}{ Real Income Produced } & \\
\hline & Total & Per Capita & \\
\hline 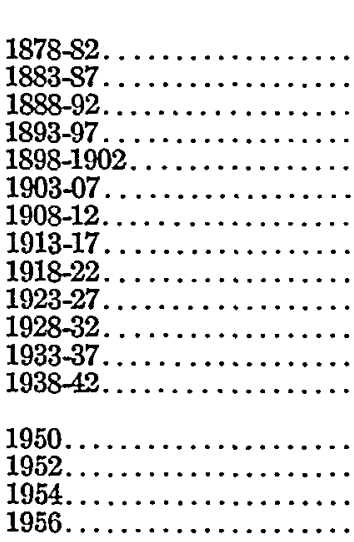 & \begin{tabular}{c|} 
Index Numbers: \\
11.5 \\
14.6 \\
17.5 \\
23.3 \\
30.1 \\
31.9 \\
39.5 \\
45.6 \\
58.2 \\
75.3 \\
100.0 \\
121.0 \\
151.3 \\
Index Numbers: \\
97.9 \\
122.0 \\
126.8 \\
153.2
\end{tabular} & \begin{tabular}{|r|}
$1928-82=100$ \\
20.1 \\
24.3 \\
28.0 \\
35.6 \\
44.0 \\
43.5 \\
51.0 \\
55.0 \\
66.8 \\
80.7 \\
100.0 \\
122.3 \\
132.2 \\
$1994-36=100$ \\
80.5 \\
98.1 \\
98.9 \\
116.8
\end{tabular} & 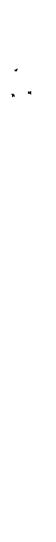 \\
\hline
\end{tabular}

Nore: : All data except 1950 and 1952 refer to calendar years; 1950 and 1952 fiscal years run from April 1 to March 31 of year following. SOURCE: KAZUEHI OHKAWA ET AL., TEE GROWTH RATE of THE JAPANESE ECoNouY SENCE 1878, at 18-20 (1957); J. B. CoHEN, JAPAN'B Postwar Econost 45 (1958).

total population, the gainfully occupied population in primary industry was smaller in I940 than in 1880, as is shown in table three. Demobilization and food shortages after World War II have reversed temporarily this trend out of agriculture in absolute, although not in percentage, terms. The increase in nonagricultural employment is reflected in the rise of Japanese labor productivity. It is one of the principal differences between the results of population growth in the Japanese and the Indian settings. No one denies the existence of "disguised unemployment" in the Japanese countryside, even in good times, particularly since World War II; but such unemployment has not become in Japan the overpowering problem that it has been in India. ${ }^{21}$

Correlated with this shift from agriculture to manufacturing and (particularly) services has been a shift from rural areas to large cities. Detailed rural-urban breakdowns are available for the three years 1920 , I930, and 1955. During this interval of approximately a generation, the percentage of the population in large cities or shi tripled; it was eighteen per cent in 1920, twenty-four per cent in 1930 , and 56.3 per cent in 1955. The percentage in the six largest cities alone rose from 9.8 to Ir.8 to 15.9. In the five-year period $1950-55$, nearly seventy per cent of the total increase was attained by the prefectures including these six cities. ${ }^{22}$

${ }^{21}$ Some Japanese authorities feel that "disguised unemployment" may become such a problem in the mid-rg60's, following a bulge in the working-age population, which, in turn, reflects the postwar baby boom. For a summary of various Japanese estimates of the present magnitude of disguised unemployment, see Shigeto Tsuru, Essays on Japanese Economy 85-90 (1958).

${ }^{23}$ Taeuber, op. cit. sipra note 17 , at 78 ; Facts about the Population of Japan: Latest Data and 
TABLE III

Sectoral Distribution of Gainfully Occupied Population, Japan, Selected Periods, $1878-195^{8}$

(MILLIONS AND RERCENTAGES) ${ }^{\mathrm{a}}$

\begin{tabular}{|c|c|c|c|c|}
\hline Period & Primary & Secondary & Tertiary & Total \\
\hline 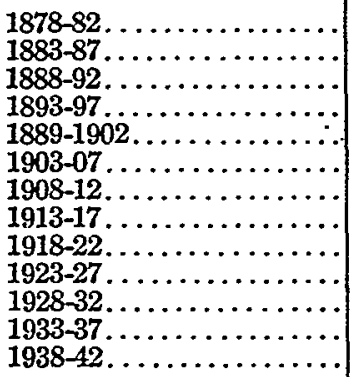 & $\begin{array}{l}16.1(82.1) \\
16.7(78.8) \\
17.2(76.1) \\
17.4(73.1) \\
17.3(70.0) \\
17.0(66.4) \\
16.5(63.0) \\
15.7(59.3) \\
14.9(54.7) \\
14.8(51.9) \\
14.8(50.5) \\
14.7(47.7) \\
14.4(44.7)\end{array}$ & $\begin{array}{l}1.1(5.6) \\
1.6(8.5) \\
2.0(8.9) \\
2.5(10.5) \\
2.9(11.8) \\
3.4(13.3) \\
3.9(14.9) \\
4.3(16.2) \\
4.7(17.3) \\
4.9(17.2) \\
4.9(16.7) \\
6.0(19.5) \\
7.6(23.6)\end{array}$ & $\begin{array}{r}2.4(12.3) \\
2.9(13.7) \\
3.4(15.0) \\
3.9(16.4) \\
4.5(18.2) \\
5.2(20.3) \\
5.8(22.1) \\
6.4(24.5) \\
7.6(28.0) \\
8.8(30.9) \\
9.6(32.8) \\
10.1(32.8) \\
10.2(31.7)\end{array}$ & $\begin{array}{l}19.5(100.0) \\
21.2(100.0) \\
22.6(100.0) \\
23.8100 .0) \\
24.8(100.0) \\
25.6(100.0) \\
26.2(100.0) \\
26.5(100.0) \\
27.1(100.0) \\
28.4(100.0) \\
29.3(100.0) \\
30.8(100.0) \\
32.2(100.0)\end{array}$ \\
\hline 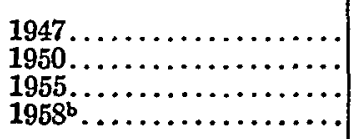 & $\begin{array}{l}17.8(53.5) \\
17.2(48.3) \\
16.1(41.2) \\
16.0(37.1)\end{array}$ & $\begin{array}{r}7.4(22.2) \\
7.8(21.9) \\
9.3(23.8) \\
11.2(26.0)\end{array}$ & $\begin{array}{r}8.1(24.3) \\
10.6(29.8) \\
13.7(35.0) \\
15.9(36.9)\end{array}$ & $\begin{array}{l}33.3(100.0) \\
35.6(100.0) \\
39.2(100.0) \\
43.1(100.0)\end{array}$ \\
\hline
\end{tabular}

Nores: * Figures are rounded and-may not add to totals

Notzs: b Estimate for 1958 (Statistics Bureau, Office of Prime Minister) are not strictly comparsble with other estimates (Census Bureau, Ministry of Welfare).

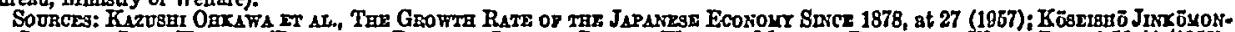

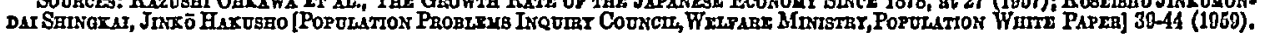

Detailed analysis of population changes in terms of birth and death rates has been possible in Japan since 1900, with the exception of the war years. Both these rates have trended downward since the 1930's, except for an immediate postwar baby boom, which lasted from mid 1946 to early 1949 . Despite a dramatic fall of the Japanese death rate below that of many European nations, ${ }^{23}$ the birth rate has fallen yet more rapidly, so that the rate of natural increase has been declining. Detail is shown in table four.

These results seem to conform to the following hypothesis regarding birth rates: birth rates rise with income for each occupational and social group in the population, along with expenditures for consumption goods generally. The birth rate of occupational and social groups high in the social "pecking order" is, however, significantly below the birth rate for groups of lower status, with the income variable held constant. Those near the top of the social pyramid would be expected to prefer fewer high-quality children to a larger quantity of the "standard product." This is also true of their purchases of other "consumer goods." Hence, the shift in the proportion of gainfully employed away from agriculture to higher-status urban

ANalysts 8 (Mainichi Newspapers, Population Problems Research Council Series No. 17, 1960). Figures are not corrected for changes in the boundaries of local units or for the reclassification of urban places.

${ }^{23}$ While the Japanese crude death rate is below that of any European country exccpt the Netherlands, this is partially attributable to the relative youth of the Japanese population. Japan's age-specific death rate remains above that of the United States and France. Cf. Yuzo Monito, FACTS ADOUT THE Population of Japan 29-3I (Mainichi Newspapers, Population Problems Research Council Series No. I $_{4}$, x956). 


\section{TABLE IV}

Crude Birth, Death, and Natural Increase Rates, Japan, Selected Years, 1900-1956 (PER THOUSAND)

\begin{tabular}{|c|c|c|c|}
\hline Year & Birth & Death & $\begin{array}{l}\text { Natural } \\
\text { Increase }\end{array}$ \\
\hline 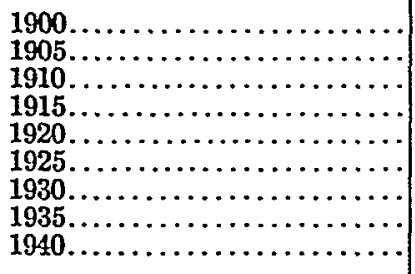 & $\begin{array}{l}31.8 \\
30.6 \\
34.0 \\
33.2 \\
36.3 \\
35.0 \\
32.4 \\
31.7 \\
29.0\end{array}$ & $\begin{array}{l}20.3 \\
21.1 \\
21.1 \\
20.1 \\
25.4 \\
20.3 \\
18.2 \\
16.8 \\
16.2\end{array}$ & $\begin{array}{r}11.4 \\
9.4 \\
12.9 \\
13.1 \\
10.9 \\
14.7 \\
14.2 \\
14.9 \\
12.7\end{array}$ \\
\hline 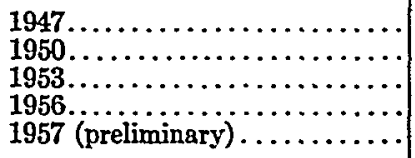 & $\begin{array}{l}34.3 \\
28.1 \\
21.5 \\
18 . \\
17.2\end{array}$ & $\begin{array}{r}14.6 \\
10.9 \\
8.9 \\
8.0 \\
8.0\end{array}$ & $\begin{array}{r}19.7 \\
17.2 \\
12.6 \\
10.4 \\
8.9\end{array}$ \\
\hline
\end{tabular}

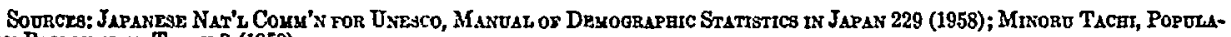
tron Phoblzub of Todar 3 (1958).

occupations, which has been a feature of development in Japan as elsewhere, reduces birth rates if income stays constant. An increase in per capita income unaccompanied by such an occupational shift tends, however, to increase birth rates. In Japan, the effect of the occupational shift on the birth rate has, since the I920's, prevailed over the effect of rising incomes. This dominance is likely to continue over the next decade or generation, but may not do so if Japan reaches a state of genuine affluence.

In terms of the economics of population, as outlined in part one, the Japanese record is that of a country approaching a population equilibrium considerably above the subsistence level by means of a lowering of both birth and death rates. Four authoritative Japanese population projections of the I950's also point in this direction. The maxima anticipated during the Ig80's apparently lie somewhat to the right of points like $\gamma_{3}$ on figure five, at the intermediate income level $y_{2}$. The projections themselves are summarized as table five. ${ }^{24}$ If our equilibrium analysis is valid, the decreases anticipated for the period I895-2000 represent an approach to equilibrium by damped oscillations. ${ }^{25}$ Of the four projections, the latest efforts (1955, I957) have semi-official status and are available in greatest detail, including estimates at annual intervals from I955 to I975 and at five-year intervals from 1975 to 2015 .

\footnotetext{
${ }^{26}$ The projection techniques used by contemporary Japanese demographers are presented in JAPANESE Nat'l Comm'n for Unesco, Mandal of Demographic Statistics in Japan i76-86 (1958). These seem somewhat mechanical and might be improved by more attention to variables such as income and urbanization.

${ }^{20}$ Sce W. J. Baumor, Economic Drnamics ch. ro (2d ed. 1959).
} 
TABLE V

Four Projections of Japanese Population, ig60-2000 (Millions) .

\begin{tabular}{|c|c|c|c|c|c|}
\hline Year & $\begin{array}{c}\text { Tachi } \\
\text { Projection } \\
\text { (1952) }\end{array}$ & $\begin{array}{c}\text { Takagi } \\
\text { Projection } \\
\text { (1953) }\end{array}$ & $\begin{array}{l}\text { Welfare Ministry } \\
(1955)\end{array}$ & $\begin{array}{l}\text { Projections } \\
\text { (1957) }\end{array}$ & $\cdot$ \\
\hline $\begin{array}{l}1960 \ldots \ldots \ldots \ldots \\
1970 \ldots \ldots \ldots \ldots \ldots \\
1980 \ldots \ldots \ldots \ldots \\
1990 \ldots \ldots \ldots \ldots \\
2000 \ldots \ldots \ldots \ldots \ldots\end{array}$ & $\begin{array}{r}92.9 \\
100.3 \\
106.4 \\
108.0 \\
106.4\end{array}$ & $\begin{array}{r}93.2 \\
99.8 \\
105.6 \\
107.1 \\
105.0\end{array}$ & $\begin{array}{r}93.2 \\
96.3 \\
103.1 \\
106.9 \\
106.4\end{array}$ & $\begin{array}{r}93.4 \\
99.6 \\
104.6 \\
104.2 \\
101.4\end{array}$ & \\
\hline
\end{tabular}

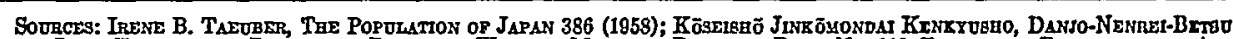

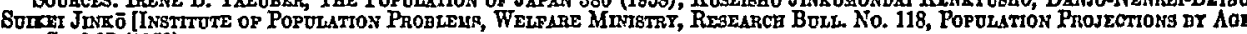
AND SEx] 27 (i959).

\section{III}

\section{Japanese Population: 1945 to Datb}

A controversial issue in Japanese demography is the interpretation of the record since I945, and particularly since I950. The conventional view presents this period as a sharp break with the past. Certainly, the declines of birth and death rates since 1950 are sharper than expected from the extrapolation of prewar trends. ${ }^{20}$ Certainly also, the decline in the birth rate has been accompanied by an active population-control movement. Thus, we find the Japanese demographer Kitaoka asserting: "In world population history, there is found no such drastic decrease in the birth rate as in recent Japan."27 The American demographer Thompson, who has had Japanese experience, assesses the significance of the alleged break with the past even more highly: ${ }^{28}$

The rapid acceptance of birth control by the Japanese people is one of the most encouraging events of recent times. It leads one to hope that other countries will follow Japan's example in attempting to make a rational adjustment of population to the resources available for its support.

Our own view, perhaps reflecting a "theoretical" bias, considers the postwar Japanese population record as, at most, a minor acceleration of trends already in progress. It considers the family-limitation movement as little more than the conspicuously visible instrument of one such trend, much as the trade-union movement was in many countries in the late I940's the conspicuously visible instrument of adjusting money wage rates to inflation arising from wartime monetary expansionan adjustment that would have almost certainly come about with no such movement in existence. ${ }^{29}$

${ }^{20}$ Mrs. Taeuber illustrates this point graphicaily. See TAeurf, op. cit. supra note 17, at 365, fig. 27.

27 Jutrsu Kitaoka, Over-Population and Family Planning in Japan I (Science Council of Japan, Division of Economics and Commerce, Economic Series No. I4, 1957).

${ }^{28}$ Warrex S. Thompson, Poptlatio: and Progkzss in the Far Last 7 (1960).

${ }^{20}$ This interpretation of the role of the trade union movement is expressed most strongly in Friedman, Some Comments on the Significance of Labor Unions for Economic Policy, in D. McC. WrichT (ED.), The IMpact of the Union ch. Io (1951); Morton, Trade Unionism, Full Employment, and Inflation, 40 
In this essay, we limit ourselves largely to an account of the major policy decisions in Japan affecting the Japanese population, at least in the short run, during the postwar period. The account begins with the Allied Occupation of $1945-52$ and continues with the recovery of Japanese sovereignty in 1952. The reader may decide for himself the proper interpretation of the accompanying changes in the population and in its rate of growth.

Occupation policy started its erratic career in virtual disregard of the Japanese population problem. This is not surprising, in that this problem had been used by the Japanese military as justification for imperialist expansion on the Asian continent and in the South Pacific. Two early Occupation policies, however commendable on other grounds, accordingly, exacerbated Japan's population crisis during the period of most severe postwar shortages and inflation (I945-48). These were the repatriation and public health programs.

Overseas Japanese to the number of $6,251,000$, approximately evenly divided between civilian and military personnel and concentrated in fertile ages, were compulsorily repatriated to Japan from continental Asia and the Pacific over the period of the Occupation. ${ }^{80}$ A partial offset was the voluntary emigration from Japan of 1,195,000 aliens, mainly Korean conscript laborers returning home. ${ }^{31}$ The net "social increase" was, therefore, 5,056,000 over the entire Occupation, 3,68I,000 in 1946 alone. ${ }^{32}$ The concentration of young men in their twenties among these repatriates was one important cause of the postwar baby boom.

At the same time, a vigorous public health program was inaugurated by the Occupation; it has been extended by the Japanese Government. It not only avoided major postwar epidemics, but reduced (with the aid of antibiotics) the traditionally high Japanese death rates from tuberculosis and other respiratory ailments. It also reduced infant mortality rates, particularly from contagious diseases; this reduction, combined with the baby boom, has given present-day Japan its remarkably youthful population concentration. 'Table six indicates some striking changes in death rates, while table seven shows the resulting increase in life expectancy at birth.

Before we consider Occupation policy toward family limitations, a thumbnail sketch of the family-limitation movement prior to 1945 may be in order. ${ }^{33}$ We have seen that abortion and infanticide were important elements in stabilizing the Japanese population during the period $1720-1850$, despite periodic legislation against them by individual feudal lords. They survived well after the Meiji Restoration of I867 in rural areas; voluntary associations were campaigning against mabiki in

AM. Econ. Rev. 13 (1950); Rees, Postwar Wage Determination in the Basic Steel Industry, 4r AM. EcoN. REv. 389 (I95I).

${ }^{30}$ For a breakdown into civilian and military categories, and also into areas from which repatriation took place, see $\mathrm{T}_{\mathrm{AEUBER}}$, op, cit. supra note 17 , at 346 .

${ }^{31}$ KrraOKA, op. cit. supra note 27 , at 12 . A large fraction of the former Korean residents are believed to have re-entered Japan illegally after Korean economic prospects were dimmed by partition and civil war. Currently (1959-60), there is a small return flow to North Korea under communist auspices.

32 Ibid.

${ }^{33}$ This resume follows KitaokA, op. cit. supra note 27 , at 43 et seq. 
TABLE VI

Japanese Death Rates, Selected Causes and Years, i920-1956 (per thousand)

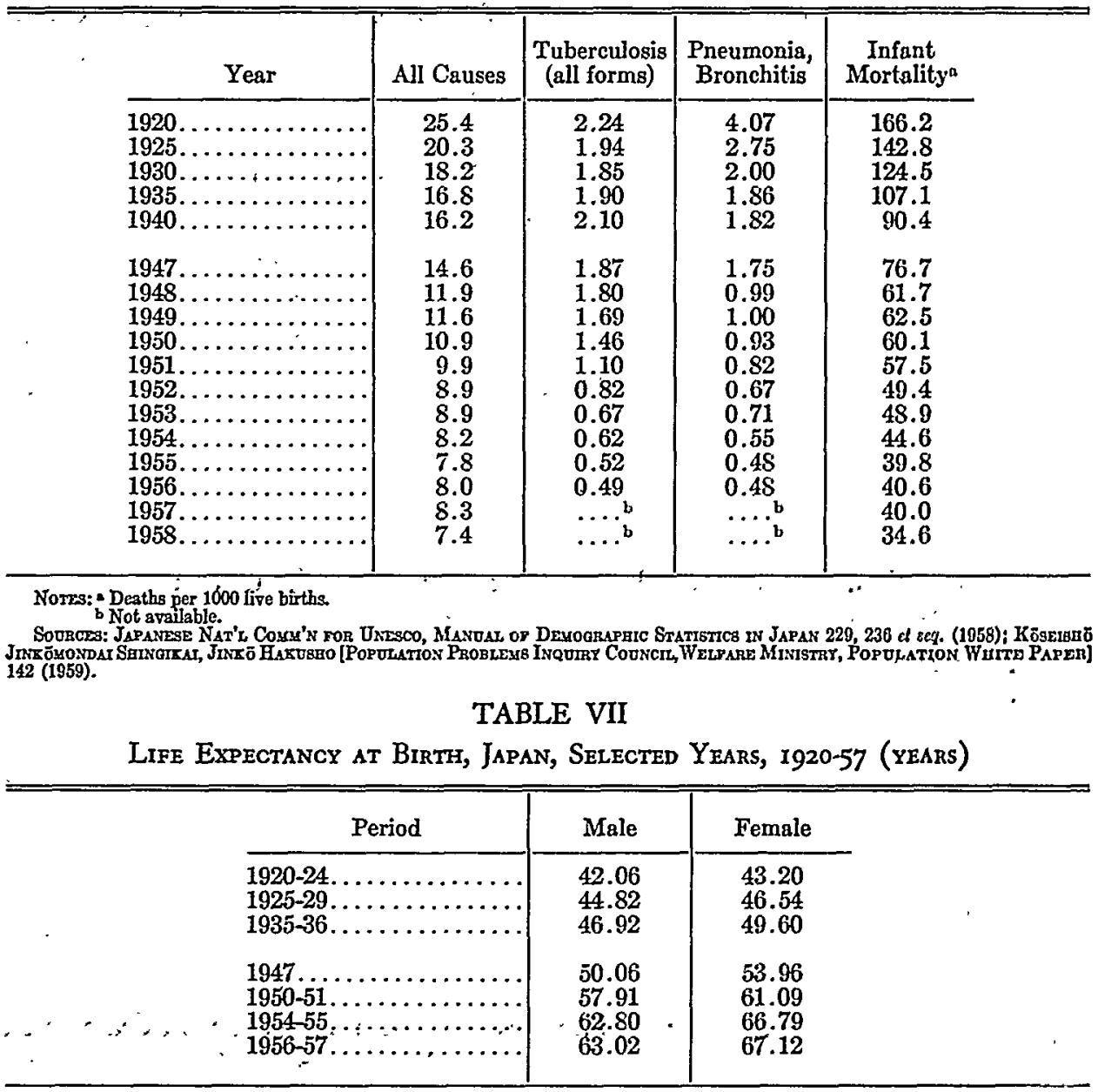

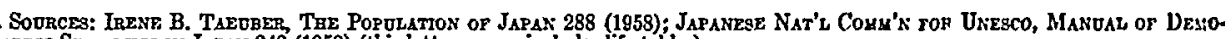
GRAPEIC StatTBTCS IN JAPAN 240 (1958) (this latter source includes Jife tables).

particular as late as the I880's and I890's, ${ }^{34}$ as not fitting for the civilized and modern nation that Japan aspired to become. Following a period of general unconcern with the population problem-save for concern regarding Japan's small size vis-à-vis China and Russia-concern with overpopulation seems to have revived with the Kome-sōdo or rice riots following World War I. ${ }^{35}$ Birth-control agitation on the western model began shortly thereafter, subject to the intermittent suspicion of the military and the police. Mrs. Margaret Sanger was prohibited from lecturing

${ }^{34}$ Information supplied the writers by Morris D. Morris.

${ }^{3 E}$ Jinkō HAxusho 3 et seq. TERAO, op. cit. supra note I7, at 8-11, gives an account of the resulting controversy. Japan's agricultural output, which had approximately kept pace with total income through the Meiji Era (I867-I912), began to fall seriously behind during World War I. Cf. KAzusHi OHxawa ET al., The Growth Rate of the Japanese Economy Since 1878, at 21-23 (1957). 
on birth control in Japan in I922; a more liberal Japanese Government.tolerated and even assisted the movement for a brief period centering in 1930; by 1937, the move. ment has been suppressed entirely by the militarists.

The family-limitation movement revived immediately after the Surrender, but met with the unexpected hostility of the early Occupation. ${ }^{36}$ Mrs. Sanger, invited to Japan by the newspaper Yomiuri, was denied an entry permit by SCAP. Pessimistic reports on Japan's natural resources by the demographers Thompson and Whelpton and by the geographer Ackerman were-suppressed temporarily for inclusion of birth control among the possible solutions Japan might adopt. ${ }^{37}$ Educational books and motion pictures illustrating contraceptive techniques were banned by SCAP as obscene-which they usually were, by small-town American standards.

When the statistics of the baby boom became known, however, the Occupation modified its position in response to near-panic among the Japanese. Public advocacy of birth control by Americans remained under the ban, but the Japanese Government was permitted to set up a Population Problem Council under the Cabinet. In the same year (1948), the Occupation permitted introduction of a Eugenic Protection Law (Y $\bar{u}$ sei-hogo-hō) into the Japanese Diet, where it passed handily.

This law, as amended and broadened since its original passage, has become the Magna Charta of Japanese family limitation. Translations from its text may be found in several of the sources cited in this essay. The principal amendments and implementations have been summarized by Tachi: $:^{38}$

In I949, the Government gave permission to manufacture several kinds of contraceptives, and contraception gradually became popular but cases of induced abortion tended to grow at leaps and bounds. In order to prevent dangerous black market induced abortions, therefore, the Eugenic Protection Law was amended in May, 1949, to widely legalize induced abortion. Then, in $195 \mathrm{r}^{\circ}$, the Government decided on a policy to disseminate contraception among the people for the purpose of preventing unnecessary induced abortions with a view to protecting maternal health. In 1952, the Eugenic Protection Law was revised again to simplify procedures for legal induced abortion, while new regulations providing for guidance in contraception were added. In the same year, the Population Problems Inquiry Council was created under the Ministry of Welfare as an advisory organ on population policies, and in 1954 , the council adopted a resolution requiring the Government to take steps to disseminate family planning upon the public. In accordance with this resolution, the Government decided in the same year to enforce a policy to diffuse the knowledge of family planning with the aim to control the population increase. The Ministry of Welfare exerted efforts for individual and group guidance

${ }^{5}$ Kitsoks, op. cit. supra note 27, at 45, ascribes this hostility to Roman Catholic members of the Occupation hierarchy; but Terso, op. cit. stpra note 17 , at 21, observes that: "Had GHQ expressed some opinion favoring birth-control, not a few of the Japanese would have suspected the intention, and thought that the Allied Powers were aiming at the gradual disappearance of the race, or in other words, the genocide." (r953).

${ }^{37}$ E. A. Ackerman, Japan's Natural Resources and Them Rezation to Japan's Economic Future

${ }^{38}$ Minoru Tachi, Population Problenss of Today 5 (1958). An earlier National Eugenic Law, modeled precisely on German Nazi doctrines, had been adopted in 1940, but lapsed following the Surrender. TERAO, op. cit. stipra note $1 \%$, at 13 et seq. 
in the techniques of family planning chiefly through the 845 eugenic protection consultation centers throughout the country while private organizations, too, provided generous cooperation in this respect.

The sale of contraceptive devices is legal in Japan, as is the dissemination of detailed contraceptive information. Contraceptives are distributed gratis to the poor. Daily newspapers and women's magazines, some with circulation in the millions, have published contraceptive information widely, including simple graphic illustrations that would be banned from the mails by the United States Post Office Department. Abortions have been legalized for a number of reasons, including the semieconomic. Thus chapter three of article fourteen legalizes abortion by licensed physicians with the consent of both spouses, "if the continuance of pregnancy or the delivery seems remarkably injurious to the health of the mother due to her physical or financial condition."39 Over ninety-nine per cent of all legal abortions are performed under this provision.

Article three of the Eugenic Protection $\mathrm{Law}^{40}$ goes further, and legitimizes sterilization ("eugenic operations") for a number of reasons relating to the health of the mother and the transmission of heredity defects. It does not mention economic causes.

Survey research, sponsored mainly by the Mainichi newspapers, indicates that a large and growing percentage of Japanese families with wives below fifty years of age, particularly urban families, admit the practice of some form of contraception, as is shown in table eight. Of these, forty-four per cent give economic reasons for so doing. Other surveys show declines in the percentage of parents who expect to be supported by their children in old age from fifty-four (1950) to fortythree (I955) and thirty-nine (I959), and in the desired number of children per family from nearly four (I947) to less than two (I959).11 (The prewar average was 4.7.) Further indications of the popularity of the family-limitation movement have been the receipt of an official award by Mrs. Sanger from the Japanese Government, the election of "the Margaret Sanger of Japan" (Mrs. Kanju Kato) to the Upper House of the Japanese Diet by the largest vote in Japanese electoral history, and the choice of Tokyo as the scene of the Fifth International Conference on Planned Parenthood.".2

It is, nevertheless, apparent that abortion has been more effective than contraception in reducing the Japanese birth rate. The proportion of reported abortions to

\footnotetext{
so Krraoks, op. cit. supra note 27, at 52. (Emphasis added.) Another provision of the same art. 14 states that consent of the father is not required "where [he] is unknown or is incapable of expressing his will, or where [he] had ceased to exist for the person in question after the conception has taken place." Taeuber, op. cit, supra note 17 , at 269 .

${ }^{10}$ Reprinted in full in KrTAOKA, op. cit. supra note 27 , at 55 et seq.

${ }^{4}$ Cf. Facts About the Population of Japan: Latest Data and Analysis 5 (Mainichi Newspapers, Population Problems Research Council Series No. 17, 1956); Thospson, op. cit. supra note 28, at 70; Kitsoka, op. cit. supra note 27 , at 59 et seq.

"9r' KraOKA, op. cit. supra note 27, at 54 et seq.; Terso, op. cit. supra note 17 , at 32 et seq.
} 
TABLE VIII

Proportion of Married Couples Practicing Some Method of Contraception, JAPAN, I950-57 (PERCENTAGE)

\begin{tabular}{|c|c|c|c|c|}
\hline Year & All Japan & $\begin{array}{c}\text { Six Largest } \\
\text { Cities }\end{array}$ & $\begin{array}{c}\text { Other Urban } \\
\text { Places }\end{array}$ & Rural \\
\hline $\begin{array}{l}1950 \ldots \ldots \ldots \ldots \\
1952 \ldots \ldots \ldots \ldots \ldots \\
1954 \ldots \ldots \ldots \ldots \\
1955 \ldots \ldots \ldots \ldots \\
1957 \ldots \ldots \ldots \ldots\end{array}$ & $\begin{array}{l}19.5 \\
26.3 \\
33.2 \\
33.6 \\
39.2\end{array}$ & $\begin{array}{l}23.7 \\
34.8 \\
3 \ddot{37.7} \\
44.5\end{array}$ & 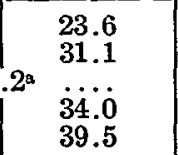 & $\begin{array}{l}17.4 \\
22.1 \\
30.4 \\
31.9 \\
36.1\end{array}$ \\
\hline
\end{tabular}

Note: * All urban places.

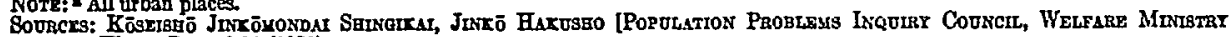
Popolation Wimte PAPER] 84 (1959).

reported births has risen above seventy per cent. ${ }^{43}$ Although many reported abortions involve illegal reasons, ${ }^{44}$ the number of unreported (illegal) abortions has been estimated to equal or to exceed the number of reported abortions legal and illegal.45

The importance of sterilization is of a much lower order of magnitude, although the proportion of unreported (illegal) sterilizations is estimated as much higher than in the case of abortion. The Muramatsu-Ogino study mentioned in the last footnote estimated the total number for 1953 as between 134,000 and 172,000 , although less than 33,000 were reported. Reported numbers of abortions and sterilizations are presented together in table nine.

\section{TABLE IX}

Reported Abortions and Sterilizations, Japan, i949-56 (thousands of operations)

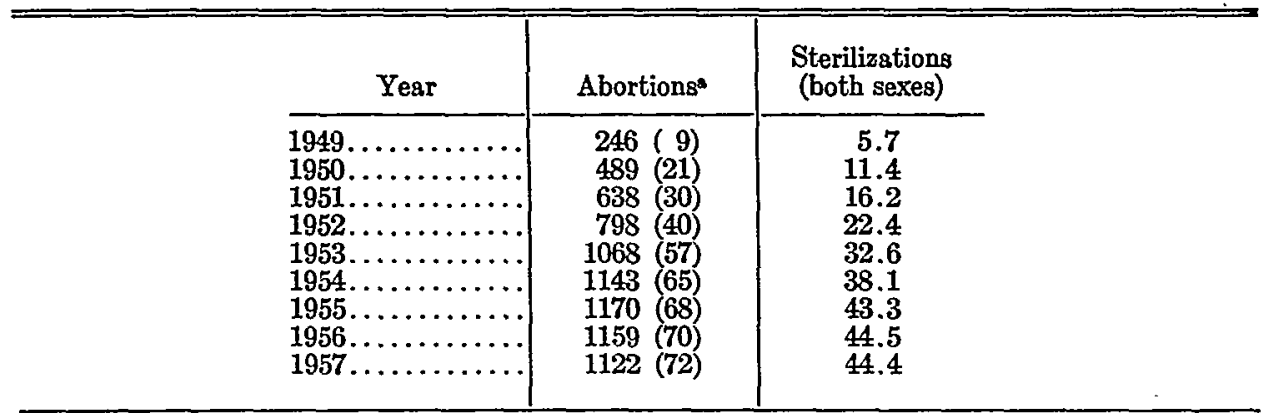

Nors: - Figurestinlparentheses are reported abortions as percentages of live births.

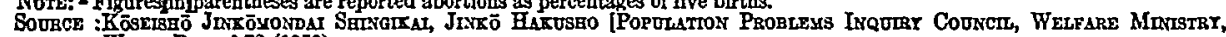
Popouation Write Paper] 72 (1959).

${ }^{43}$ Jinxō Haxusfo 44 estimates that $40 \%$ of pregnancies end in abortion.

"Krrsors, op. cit. supra note 27 , at 54, reports the following illegal reasons as mentioned frequently by patients: pregnancy in old age, too short an interval after prior childbirth, too much care for older children, no desire for more children, diffcult living conditions (especially housing), necessity for work outside the home.

${ }^{6}$ Mrs. Taeuber reports a study by Muramatsu and Ogino estimating the total number of abortions at from $1,800,000$ to $2,300,000$ in a year (1953) when reported abortions were $1,100,000$. TaEUBER, op. cit. supra note 17 , at 276 . 
There is no doubt that contraception and abortion have been the instrumentalities of the halving of the Japanese birth rate from thirty-four to seventeen per thousand population in a decade. It is, nevertheless, interesting to note as is shown in table ten, that the decline of the birth rate from baby boom to "empty kindergarten" levels has proceeded at a fairly smooth rate, regardless of the ease or difficulty of contraception and abortion, save for the two years $1950-51$. As the table shows, more than half of the total cumulative decline in the birth rate from its 1947 high was already achieved by the end of $195 x$, before the "easy abortion" amendment to the Eugenic Protection Law was passed. Furthermore, the decline of the abortion rate since 1955 was not accompanied by any increase in the birth rate. This evidence suggests to the present writers that the importance of the particular institutions of easy legal contraception and abortion in lowering the Japanese birth rate may have been exaggerated, and that other institutions (e.g., postponement of marriage, continence within marriage, illegal contraception, illegal abortion) might have brought close approximations to the same results in a Japan more affected by western prudery.

TABLE X

Decline of the Japanese Birth Rate, r947-58 (per thousand)

\begin{tabular}{|c|c|c|c|c|}
\hline & \multirow{2}{*}{ Year } & \multirow{2}{*}{$\begin{array}{l}\text { Crude Birth } \\
\text { Rate }\end{array}$} & \multicolumn{2}{|c|}{ Decline } \\
\hline & & & Simple & Cumulative \\
\hline$\ldots$ & 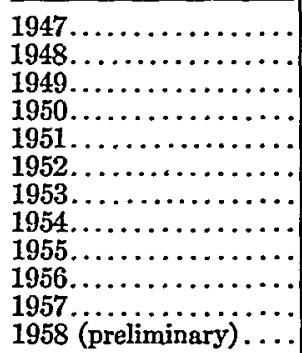 & $\begin{array}{l}34.30 \\
33.52 \\
32.97 \\
28.10 \\
25.29 \\
23.37 \\
21.48 \\
20.05 \\
19.39 \\
18.45 \\
17.20 \\
17.93\end{array}$ & $\begin{array}{l}0.78 \\
0.55 \\
4.87 \\
2.81 \\
1.92 \\
1.89 \\
1.43 \\
0.66 \\
0.94 \\
1.25 \\
-0.73\end{array}$ & $\begin{array}{r}0.78 \\
1.33 \\
6.20 \\
9.01 \\
10.93 \\
12.82 \\
14.25 \\
14.91 \\
15.85 \\
17.10 \\
16.37\end{array}$ \\
\hline
\end{tabular}

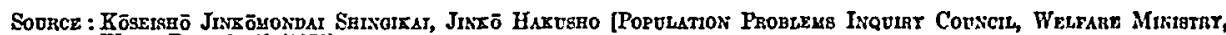
POPULATTON WHTTE PAPER] 142 (1959).

\section{CONCLUSION}

Save for the cost of abortion (especially repeated abortion) on female health, these statistics cumulate to what is for the economist an optimistic picture of Japan approaching a stable population level at the highest living standards in its history. This optimism is enhanced by the fact that national income per gainfully occupied worker doubled in only eight years (1947-55) of reconstruction and recovery.6 Even lacking the salutary experience of similar easy optimism in the 1920's and 1930's,

"OHKaws, op. cit. stspra note 35, at 234 . 
however, ${ }^{4 \pi}$ we should probably temper our sanguine projections with three caveatsone for the near and two for the long-term future.

During the middle I960's, Japan faces what may be its last population convulsion, but a severe one for all that. The baby-boom babies will come of working age tothe number of some $11,700,000$ in the decade ending in 1965 , and $8,000,000$ are expected to be added to the labor force itself. ${ }^{48}$ Will there be jobs for them at anythinglike the present wage rates of large-scale industry? If not, there will be a wave of unemployment, open or disguised, with every prospect of social upheaval or even revolution.

This problem the Japanese Government has chosen to meet in advance by longrange planning-with results, as yet, uncertain. ${ }^{49}$ Much depends on the state of the world economy and of world trade in the crucial period rg6r-1967. Duringthese years, Japan must increase exports sharply to pay for the imports required to. distribute her postwar standard of living over her larger adult population.

Japan's two longer-term population problems, assuming continued peace, are a possible resurgence of the birth rate and the rising proportion of aged persons. incapable of self-support. Japanese, traditionally fond of children, may raise birth rates voluntarily once again (without waiting for affluence as per our theory), sincethe housing situation is continuing its belated recovery from wartime damage. If so, the low birth rates of the 1950's may be seen eventually in retrospect as postponements of children to the next decade. Preliminary reports for 1958 point vaguely. in this direction. They show a slight but ominous rise in the crude birth rate as is. shown in table ten, and also increases in both marriage rates and fertility rates of: recent marriages. ${ }^{50}$ This apparent rebound may be a freak occurrence or a statistical: error; if it is real and significant, no one-knows with certainty how far it may proceed.

As Japanese life expectancy continues to increase, the proportions of aged personsto those of working age will rise. Taking fifteen and sixty years as "working agelimits," the percentage of persons sixty years of age and over to those of working: age was 12.8 in 1955 . It is expected to double by 1990 and reach 32.5 by $2000 .^{51 t}$ While this rise will be offset by the anticipated decline in the proportion of de-. pendent children, it presents, nevertheless, a problem that Japan has faced no moreresolutely than has the United States, and that Japan's comparative poverty leaves. it less well equipped to solve.

${ }^{47}$ These optimistic forecasts of the interwar period are discussed by Mrs. Taeuber in Japan and Korea: Population Growth, in Williamson \& ButrRIck, op, cit. supra note 2, ch. II.

${ }^{68}$ JAPANESE NAT'L COMM'N FOR UNESCO, op. cit. supra note 24, at 203, 206.

${ }^{10}$ The Japaniese Government has prepared Economic Planning Agency, A New Long-Range EcoNomic Plan of JAPAN (I958), covering the fiscal years $1958-62$, and in some sectors extending to r975. This plan is currently (Spring 1960 ) in process of revision in the direction of greater freedom of trade and a larger role for price adjustments.

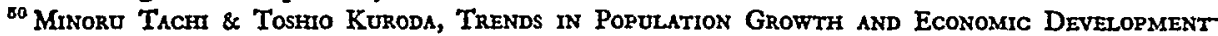
IN JAPAN 13-15 (1959), are among the Japanese population specialists inclined toward pessimism as to. the possible significance of the 1958 figures.

E1 JAPANESE NAT'L COMḾ'N FOR UNESCO, op. cit. supta note 24, at 242. 